\title{
IL-23 promotes growth and proliferation in human squamous cell carcinoma of the oral cavity
}

\author{
MASAKATSU FUKUDA ${ }^{1}$, MASAHIRO EHARA ${ }^{1}$, SEIJI SUZUKI ${ }^{1}$, \\ YOSHIHIRO OHMORI $^{2}$ and HIDEAKI SAKASHITA ${ }^{1}$
}

\author{
${ }^{1}$ Second Division of Oral and Maxillofacial Surgery, Department of Diagnostic and Therapeutic Sciences, \\ ${ }^{2}$ Division of Microbiology and Immunology, Department of Oral Biology and Tissue Engineering, \\ Meikai University School of Dentistry, 1-1 Keyakidai, Sakado, Saitama 350-0283, Japan
}

Received December 24, 2009; Accepted February 16, 2010

DOI: 10.3892/ijo_00000620

\begin{abstract}
Interleukin (IL)-23 is a heterodimeric cytokine, comprising IL-12p40 and the cloned IL-23-specific p19 subunit, was identified as a cancer-associated cytokine in a recent study. Like IL-12, IL-23 is expressed predominantly by activated dendritic cells and phagocytic cells. These cytokines antagonistically regulate local inflammatory responses in the tumor microenvironment and infiltration by intraepithelial lymphocytes. We have previously demonstrated the expression of IL-23 and its receptors in human oral squamous cell carcinoma (HOSCC) cell lines and tissue. Hence, this study investigated whether IL-23 has a role in the growth and proliferation of oral cancer cells by examining the expression kinetics of IL-23 and NF- $\mathrm{KB}$ activity, in vitro and in vivo. IL-23, which constitutively expressed in oral cancer, was enhanced by TNF- $\alpha$ and IL-23. IL-23 promotes cell proliferation in oral cancer and enhances the transport of nuclear factor $-\kappa \mathrm{B}(\mathrm{NF}-\kappa \mathrm{B}$ p65, RelA) to the nucleus in HSC-3 cells. Furthermore, luciferase reporter assay showed that IL-23 strongly induces RelA activity, and confirmed this finding by knockdown of IL-23 using RNA interference. Although RelA activity was down-regulated by anti-human IL-23p19 polyclonal antibody, used to neutralize the activity of IL-23, apoptosis was not induced. Immunohistochemistry revealed a weak IL-23 immunoreactivity in the cytoplasm of inflammatory infiltrating cells and in the cancer cells derived from 14 of 40 cases $(35 \%)$ of oral SCC. In contrast, strong RelA immunoreactivity was observed in 30 of 40 cases of SCC (75\%), especially consistent with IL-23 positive cells in SCC tissues. These data suggest that IL-23 up-regulates the growth
\end{abstract}

Correspondence to: Dr Masakatsu Fukuda, Second Division of Oral and Maxillofacial Surgery, Department of Diagnostic and Therapeutic Sciences, Meikai University School of Dentistry, 1-1 Keyakidai, Sakado, Saitama 350-0283, Japan

E-mail: fukudam@dent.meikai.ac.jp

Key words: interleukin (IL)-23, nuclear factor-kappaB (NF-кB), p65/RelA, PAb IL-23p19, TNF- $\alpha$, human oral squamous cell carcinomas and cell proliferation of oral cancer by promoting the nuclear transactivation of RelA.

\section{Introduction}

The causal relationship between chronic inflammation, innate immunity and cancer is now widely accepted, and the similarities in the regulatory mechanisms have been suggested for more than a century $(1,2)$. Although proliferation of cells alone does not cause cancer, sustained cell proliferation in an environment rich in inflammatory cells, growth factors, activated stroma, and DNA damage-promoting agents, certainly potentiates and/or promotes neoplastic risk. Interleukin (IL)-23, a heterodimeric cytokine with many similarities to IL-12, has recently been identified as a factor linking tumor-associated inflammation and a lack of tumor immune surveillance (3). IL-23 comprises a p19 subunit that associates with the IL-12p40 subunit (4), whereas IL-12 is a combination of IL-12p35 and the same IL-12p40 subunit (5). Furthermore, IL-23p19 is a molecule structurally related to not only IL-6, but also granulocyte-colony stimulating factor (G-CSF), and the p35 subunit of IL-12. Although p19 is expressed in various tissues and cell types, it lacks biological activity and only becomes biologically active when complexed with $\mathrm{p} 40$, which is normally secreted by activated macrophages and dendritic cells (DCs) (4). IL-23 uses many of the same signal-transduction components as IL-12, including the IL-12 receptor (R) ß1 subunit (IL-12Rß1), Janus kinase (Jak)2, Tyk2, signal transducer and activator of transcription (Stat)1, Stat3, Stat4, and Stat5 $(4,6)$. IL-23R, composed of the IL$12 \mathrm{R} ß 1$ and the IL-23R subunit, is also expressed in DCs, macrophages, and $\mathrm{T}$ cells (6). Consistent with the structural and biological similarities of IL-12 and IL-23, the IL-23R complex shares a subunit with that of IL-12 (IL-12Rß1); however, it does not use or detectably bind to IL-12Rß2 (4). The ability of cells to respond to either IL-12 or IL-23 is determined by expression of IL-12Rß2 or IL-23R, respectively (6). Additionally, both cytokines promote the $\mathrm{T}$ helper cell type 1 (Th1) costimulatory function of antigen-presenting cells (7). However, IL-23 does differ from IL-12 in the T cell subsets that it targets. IL-12 acts on naive $\mathrm{CD} 4^{+} \mathrm{T}$ cells, whereas IL-23 preferentially acts on memory $\mathrm{CD} 4^{+} \mathrm{T}$ cells 
(7). It has been reported that IL-12 has potent antitumor activity in a variety of murine tumor models, causing regression of established tumors (8-10) and inhibiting the formation of experimental metastases $(8,9)$ and spontaneous metastases $(11,12)$. On the other hand, it has recently been reported that genetic deletion or antibody-mediated elimination of IL-23 in mice leads to increased infiltration of cytotoxic $\mathrm{T}$ cells into the transformed tissue, rendering a protective effect against chemically-induced carcinogenesis (3). So far, it has been reported that expression of IL-23 and its receptors is detectable in activated macrophages, DCs, and keratinocytes in healthy skin (13). We have also demonstrated that the human oral squamous cell carcinoma (HOSCC) cell line, HSC-3, spontaneously expresses IL-23 and its receptors mRNA and protein (14). However, the exact mechanisms by which IL-23 promotes the development of oral SCCs remain to be elucidated.

In the present study, we first examined the expression kinetics of IL-23 in oral cancer cells in vitro and in vivo in order to clarify the role of IL-23 in these cells. We demonstrated that IL-23, which constitutively expressed in oral cancer cells, is enhanced by TNF- $\alpha$ and IL-23. It has already been reported that TNF- $\alpha$ induces NF- $\kappa$ B activation via a common pathway based on the phosphorylation-induced

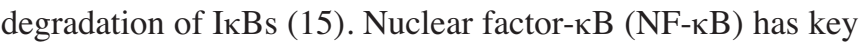
roles in inflammation, immune response, tumorigenesis and protection against apoptosis (16-18). In most cell types, $\mathrm{NF}-\kappa \mathrm{B}$ remains bound to $\mathrm{I} \kappa \mathrm{B} \alpha$ protein, and thereby inactive, in the cytoplasm $(19,20)$. After stimulation by various reagents, $\mathrm{I} \kappa \mathrm{B} \alpha$ is rapidly phosphorylated by the IкB kinase (IKK) complex and degraded by the proteasome, allowing NF- $\mathrm{B}$ to translocate to the nucleus and activate its target gene $(15,17,21)$. We also showed that IL-23 increased cell proliferation in oral cancer and up-regulated translocation of NF- $\mathrm{KB}$ p65, RelA into the nucleus of HSC-3 cells. We further found that IL-23 induced RelA-dependent transcriptional activity in oral cancer cells. The expression and distribution of IL-23 and RelA was also examined in oral SCC tissues.

\section{Materials and methods}

Reagents. Mouse anti-human NF-кB p65/RelA monoclonal antibody (MAb RelA) and goat anti-human IL-23p19 polyclonal antibody (PAb IL-23p19) were purchased from Santa Cruz Biotechnology (Santa Cruz, CA, USA) for immunoblot analysis and immunohistochemistry. MAb $\beta$-actin was obtained from Sigma (St. Louis, MO, USA). PAb IL-23p19 for the neutralization of human IL-23 bioactivity was purchased from R\&D Systems (Minneapolis, MN, USA). Goat anti-human IgG (H\&L) antibody (R\&D Systems) was used as a control for the neutralization of human IL-23 bioactivity. Recombinant human TNF- $\alpha$ and IL-23 (R\&D Systems) were used for the stimulation of cell lines.

Cell culture. Human oral squamous cell carcinoma (HOSCC: HSC-2, HSC-3, HSC-4 and Ca9-22) cells (obtained from the American Type Culture Collection, ATCC, Manassas, VA, USA) were respectively maintained in RPMI-1640 medium supplemented with $10 \%$ heat-inactivated fetal bovine serum (FBS), $100 \mathrm{IU} / \mathrm{ml}$ penicillin and $100 \mu \mathrm{g} / \mathrm{ml}$ streptomycin, and grown to confluency in $25 \mathrm{~cm}^{2}$ culture flasks at $37^{\circ} \mathrm{C}$ in a humidified $5 \% \mathrm{CO}_{2}$ incubator until required.

RNA extraction and real-time quantitative RT-PCR. Total RNA was extracted from monolayer HOSCC cells $\left(1 \times 10^{6}\right.$ cells $\left./ \mathrm{ml}\right)$ by the acid-guanidinium-phenol-chloroform (AGPC) method reported previously (22). To confirm the expression patterns of up-regulated or down-regulated IL-23 and RelA genes in HOSCC cells, especially HSC-3 cells, derived from metastatic lymph node of tongue cancer, treated with or without TNF- $\alpha$ (10 ng/ml), IL-23 (10 ng/ml), or IL-23 (10 ng/ml) + PAb IL23p19 $(0.8 \mu \mathrm{g} / \mathrm{ml})$, real-time quantitative RT-PCR analyses were performed using a Bio-Rad iCycler system (Bio-Rad, Tokyo, Japan) and an iScript One-Step RT-PCR kit with SYBR Green I (Bio-Rad) according to the manufacturer's instructions. Briefly, the mRNAs were reverse-transcribed into cDNAs at $50^{\circ} \mathrm{C}$ for $10 \mathrm{~min}$ and reverse transcriptase was inactivated at $95^{\circ} \mathrm{C}$ for $5 \mathrm{~min}$. PCR amplification was performed for 45 cycles of $95^{\circ} \mathrm{C}$ for $10 \mathrm{sec}$ and $56^{\circ} \mathrm{C}$ for $30 \mathrm{sec}$ and was followed by detection. PCR primers were designed and synthesized by Sigma-Aldrich (Ishikari, Japan) by following special design criteria for real-time PCR primers. The following primer sequences were used in the PCR reactions: IL-23p19 forward: TGC TAG GAT CGG ATA TTT TCA CAG G; IL-23p19 reverse: GAG GCT TGG AAT CTG CTG AGT C; RelA forward: AGG CGA GAG GAG CAC AGA TAC; RelA reverse: CGG CAG TCC TTT CCT ACA AGC; GAPDH forward: CAG CCT CAA GAT CAT CAG CA; GAPDH reverse: ACA GTC TTC TGG GTG GCA GT. Each sample was tested in triplicate and for each reaction the corresponding no-RT mRNA sample was included as a negative control. The relative mRNA level of each sample for each gene was normalized to the mRNA level of GAPDH, a housekeeping gene. The results were analyzed with the Bio-Rad iCycler Software 3.0 and Microsoft Excel 97 and presented as fold induction compared with the quantity of GAPDH mRNA (set at 1). The specificity of PCR products was assessed by melting curve data and agarose gel electrophoresis to determine product size and to confirm that no byproducts were formed.

Enzyme-linked immunosorbent assay (ELISA). Monolayer HSC- 3 cells $\left(1 \times 10^{6}\right.$ cells $\left./ \mathrm{ml}\right)$ were washed once with PBS and incubated with TNF- $\alpha(10 \mathrm{ng} / \mathrm{ml})$ for the indicated time period in RPMI-1640 medium containing 10\% FBS. The culture supernatants from HSC-3 cells were harvested and concentrated 10-fold by using an ultrafiltration kit (Millipore, Tokyo, Japan). The amounts of secreted IL-23 (heterodimeric form) protein in the supernatants were determined by a solidphase sandwich ELISA, using ELISA kits (BioSource International, Camarillo, CA, USA) according to the manufacturer's instructions. After adding the stop solution, the optical density (OD) was determined by measuring the absorbance of the dye solution at $450 \mathrm{~nm}$. This ELISA detects only the heterodimer form of IL-23, not the separate subunits. Each experiment was performed in triplicate. The minimum detectable dose of the IL-23 heterodimer is $1.5 \mathrm{pg} / \mathrm{ml}$.

Cell proliferation assay. The assay is based on the cleavage of the tetrazolium salt WST-8 to formazan by cellular 
mitochondrial dehydrogenases, the activity of which increases proportionally to the number of viable cells. The formazan dye produced by viable cells was quantified as an index of cell proliferation. Monolayer HSC-3 cells $\left(2 \times 10^{4}\right.$ cells/100 $\mu 1 /$ well $)$ were incubated for $24 \mathrm{~h}$ on a 96 -well plate. The cells were washed once with PBS and incubated with TNF- $\alpha(10 \mathrm{ng} / \mathrm{ml})$ or IL-23 $(10 \mathrm{ng} / \mathrm{ml})$ in the presence or absence of PAb IL$23 \mathrm{p} 19(0.8 \mu \mathrm{g} / \mathrm{ml})$ for various time periods $(4,8,12,24$ and $48 \mathrm{~h}$ ) in RPMI-1640 medium containing $10 \%$ FBS. Ten microliters of WST-8/ECS solution (Dojindo Laboratories, Tokyo, Japan) was added to each well and incubated with the cells for $2 \mathrm{~h}$ at $37^{\circ} \mathrm{C}$ in a humidified $5 \% \mathrm{CO}_{2}$ incubator. The cells were then shaken thoroughly for $1 \mathrm{~min}$ on a shaker. The relative viable cell number was determined by measuring absorbance of the dye solution at $450 \mathrm{~nm}$.

Morphological observation. HSC-3 cells $\left(1 \times 10^{4}\right.$ cells $\left./ \mathrm{ml}\right)$ were maintained with RPMI-1640 supplemented on a $10 \mathrm{~cm}^{2}$ glass plate (Iwaki, Chiba, Japan). The cells were washed once with PBS and incubated with $0.8 \mu \mathrm{g} / \mathrm{ml}$ of PAb IL-23p19 for $24 \mathrm{~h}$ in RPMI-1640 medium with $10 \%$ FBS. The cellular morphology was directly observed under a confocal laser microscope.

Protein extraction. To examine RelA translocation to the nucleus, we used a subcellular proteome extraction kit (S-PEK, Calbiochem, Darmstadt, Germany) according to the manufacturer's instructions to extract the cytoplasmic, cell membrane, and nuclear fractions of HSC-3 cells. Cells were treated with or without $10 \mathrm{ng} / \mathrm{ml}$ of TNF- $\alpha, 10 \mathrm{ng} / \mathrm{ml}$ of IL-23, $0.8 \mu \mathrm{g} / \mathrm{ml}$ of PAb IL-23p19, or IL-23 + PAb IL-23p19 for $30 \mathrm{~min}$ and then $5 \times 10^{6}$ cells were pelleted by centrifugation, washed twice, and then resuspended in $1 \mathrm{ml}$ of ice-cold Extraction I buffer containing $5 \mu \mathrm{l}$ of protease inhibitor mixture and incubated for $10 \mathrm{~min}$ at $4^{\circ} \mathrm{C}$ with gentle agitation. The cell suspension was then centrifuged at $1,000 \mathrm{xg}$ at $4^{\circ} \mathrm{C}$ for $10 \mathrm{~min}$. The supernatant was used as the cytoplasmic fraction and the pellet was resuspended in $1 \mathrm{ml}$ of ice-cold Extraction II buffer containing $5 \mu \mathrm{l}$ of protease inhibitor mixture and incubated for $30 \mathrm{~min}$ at $4^{\circ} \mathrm{C}$. The sample was then centrifuged at $6,000 \mathrm{x} \mathrm{g}$ at $4^{\circ} \mathrm{C}$ for $10 \mathrm{~min}$ and the supernatant was used as the cell membrane fraction. The pellet was resuspended in $500 \mu \mathrm{l}$ of ice-cold Extraction III buffer containing $5 \mu \mathrm{l}$ of protease inhibitor mixture and $1.5 \mu \mathrm{l}$ of Benzonase ${ }^{\circledR}$ and incubated for 10 min at $4^{\circ} \mathrm{C}$ with gentle agitation. The sample was then centrifuged at $7,000 \mathrm{xg}$ at $4^{\circ} \mathrm{C}$ for $10 \mathrm{~min}$ and the supernatant was used as the nuclear fraction. Each sample was subjected to immunoblot analysis.

Immunoblot analysis. For the detection of IL-23 and RelA protein by gel electrophoresis, $30-\mu \mathrm{g}$ and $10-\mu \mathrm{g}$ protein samples were mixed with an equal volume of SDS-PAGE sample buffer and boiled for $5 \mathrm{~min}$. These amounts were loaded per lane and separated on a polyacrylamide gel of appropriate percentage, then the proteins were electroblotted onto nitrocellulose membranes. Subsequent immunoblot analysis was carried out according to the method reported previously (22).

Transfection of HOSCC cells and luciferase reporter assay. HSC-3 cells ( $1 \times 10^{6}$ cells $\left./ \mathrm{ml}\right)$ were cultured for $12 \mathrm{~h}$ in $24-w e l l$

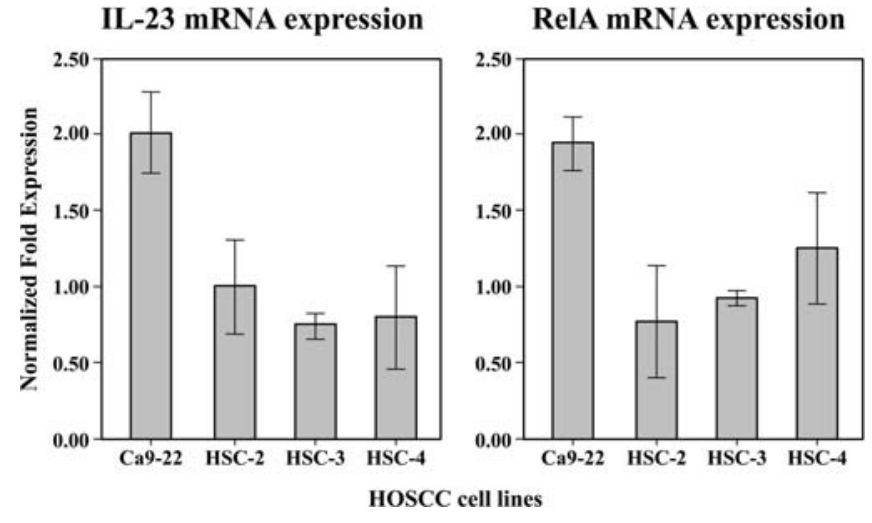

Figure 1. Detection of IL-23 and RelA mRNAs by real-time quantitative RT-PCR in HOSCC cells. IL-23 and RelA mRNAs were endogenously expressed in all HOSCC cell lines. Each column and bar represents the mean \pm SEM of three independent experiments.

culture plates containing RPMI-1640 supplemented with 10\% FBS. pTKкB2luc, a thymidine kinase (TK) luciferase construct containing five copies of the $\kappa \mathrm{B}$ motif from the CXCL10/IP-10 gene, was kindly provided by Professor Y. Ohmori (23). Cells were transiently transfected with pTKкB2luc and pRL-TK reference Renilla luciferase plasmid (Promega, Madison, WI, USA) by using FuGENE transfection reagents (Roche, Nutley, NJ, USA), according to the manufacturer's instructions. At $24 \mathrm{~h}$ after transfection, the cells were treated with TNF- $\alpha(10 \mathrm{ng} / \mathrm{ml}), \mathrm{IL}-23(10 \mathrm{ng} / \mathrm{ml})$, TNF- $\alpha(10 \mathrm{ng} / \mathrm{ml})$ together with PAb IL-23p19 $(0.8 \mu \mathrm{g} / \mathrm{ml})$, IL-23 (10 ng/ml) together with PAb IL-23p19 $(0.8 \mu \mathrm{g} / \mathrm{ml})$, or TNF- $\alpha(10 \mathrm{ng} / \mathrm{ml})$ together with goat anti-human $\mathrm{IgG}$ $(0.8 \mu \mathrm{g} / \mathrm{ml})$, or IL-23 $(10 \mathrm{ng} / \mathrm{ml})$ together with goat anti-human $\operatorname{IgG}(0.8 \mu \mathrm{g} / \mathrm{ml})$ for various time periods $(0,1,4,8$ and $24 \mathrm{~h})$. The activity of firefly and Renilla luciferase was assayed by using reagents provided by Promega, according to the manufacturer's instructions. For standardization of transfection efficiency, the luciferase activity derived from pTKкB2luc was normalized to the activity of Renilla luciferase. The pGL3 control luciferase plasmid was purchased from Promega.

RNA-mediated interference. Small interfering RNAs (siRNAs) specific for human IL-23 and scrambled (control) were synthesized by Sigma-Aldrich. The sense and antisense strand sequences of the oligonucleotides were as follows. IL-23 siRNA sense, CAG CAA CCC UGA GUC CCU ATT; antisense, UAG GGA CUC AGG GUU GCU GTT; control siRNA sense, CGG AAC UCG AUA CUA CCC CTT; antisense, GGG GUA GUA UCG AGU UCC GTT. FuGENE 6 transfection reagent was mixed with $100 \mathrm{nM}$ IL-23 or $100 \mathrm{nM}$ control siRNA $(3: 3.4 \mu \mathrm{l})$ in serum-free medium, to a total volume of $500 \mu \mathrm{l}$ and incubated for $30 \mathrm{~min}$ at room temperature. For IL-23 knockdown, HSC-3 cells $\left(1 \times 10^{5}\right.$ cells/ml) were rinsed with serum-free medium and transfected in 24-well plates with a RelA-dependent luciferase reporter plasmid and either an IL-23 siRNA duplex or a control siRNA using FuGENE 6 transfection reagents for $48 \mathrm{~h}$ at $37^{\circ} \mathrm{C}$. Cells were treated with TNF- $\alpha$ for $4 \mathrm{~h}$, and subjected to immunoblot analysis and luciferase reporter assay. 
A
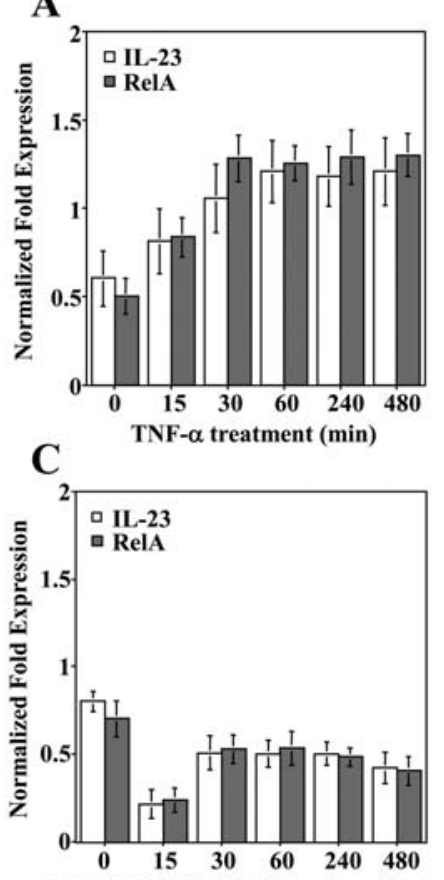

IL-23 + PAb IL-23p19 treatment $(\min )$
B
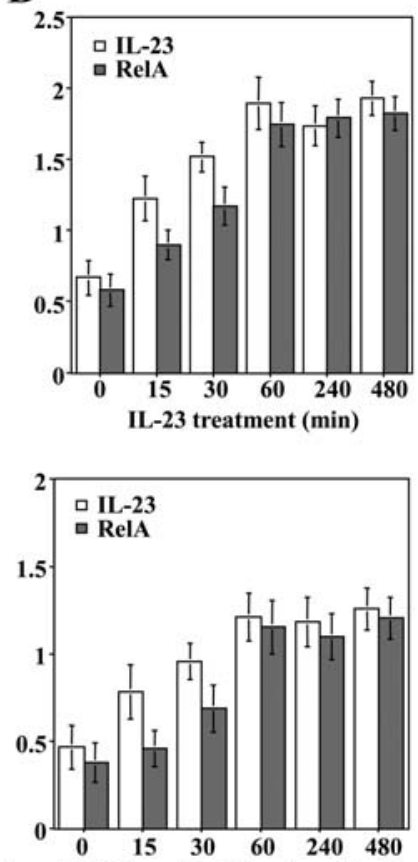

IL-23 + goat IgG treatment (min)

Figure 2. Effects of TNF- $\alpha$ or IL-23 on IL-23 and RelA mRNA expression. TNF- $\alpha$ and IL-23 induced a rapid increase in the levels of both IL-23 and RelA mRNA. TNF- $\alpha$ stimulation led to a more rapid peak of IL-23 and RelA expression at 30 min (A), after which mRNA levels reached a plateau, whereas IL-23 treatment led to a peak of expression of both genes at $60 \mathrm{~min}$ and subsequent plateau (B). The relative quantity of IL-23 and RelA mRNA is suppressed in HSC-3 cells by the neutralization of IL-23 (C). The goat IgG was used as a control antibody for the effect of PAb IL-23p19. Each column and bar represents the mean \pm SEM of three independent experiments.

Primary tumor samples. Formalin-fixed, paraffin-embedded specimens were obtained from 40 patients with SCC treated in the Department of Oral and Maxillofacial Surgery, Meikai University Hospital, Japan. The pathological diagnosis of oral lesions was based on histological examination of hematoxylin and eosin-stained slides and made according to the WHO classification (24). The postsurgical TNM stage was determined according to the pTNM pathological classification of the UICC (International Union Against Cancer) (25). All specimens were obtained from surgical biopsies. None of the patients had undergone preoperative chemotherapy or radiotherapy. The labeling index was defined as the percentage of tumor cells displaying immunoreactivity, and calculated by counting the number of IL-23p19 and $\mathrm{NF}-\kappa \mathrm{B}-$ positive tumor cells among 1,000 tumor cells in each section. Tissue sections with $<5 \%$ reactive cells were defined as negative (-), and those with $\geq 5 \%$ positive reactive cells were defined as positive $(+)$.

Immunohistochemical examination. The sections were immersed in absolute methanol containing $0.3 \% \mathrm{H}_{2} \mathrm{O}_{2}$ for $20 \mathrm{~min}$ at room temperature to block endogenous peroxidase activity. Immunohistochemistry was carried out with each antibody according to the method reported previously (14).

Ethical considerations. The study was approved by the Research Ethics Committee of the Meikai University School of Dentistry, Saitama, Japan (reference number: A0801).

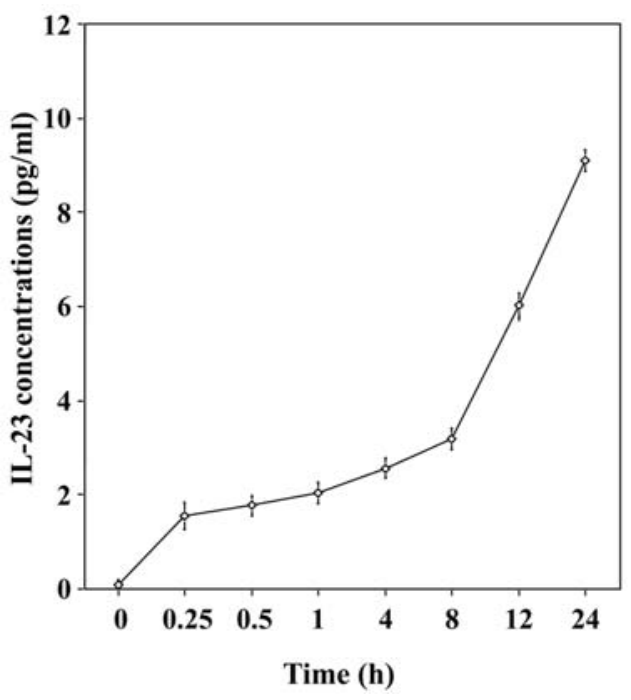

Figure 3. ELISA. HSC-3 cells were treated with TNF- $\alpha(10 \mathrm{ng} / \mathrm{ml})$ for the indicated times before harvest of culture supernatants. After concentration of the supernatants by means of an ultrafiltration kit, the levels of IL-23 protein were measured by ELISA. The maximum amount of TNF- $\alpha$-induced heterodimeric IL-23 was observed after $24 \mathrm{~h}$ and this was an increase of over 8-fold compared with cells not treated with TNF- $\alpha$. Each column and bar represents the mean \pm SEM of three independent experiments.

\section{Results}

Detection of IL-23 and RelA gene expression in HOSCC cells stimulated with TNF- $\alpha$ or IL-23. To investigate the regulation of expression of IL-23 and RelA mRNA in HOSCC cells by TNF- $\alpha$ or IL-23 treatment, real-time quantitative RT-PCR analysis was carried out using specifically designed primer pairs. Firstly, the relative level of IL-23 and RelA mRNA was determined in HSC-2, HSC-3, HSC-4, and Ca9-22 cell lines without TNF- $\alpha$ or IL-23 treatment (Fig. 1). IL-23 and RelA mRNAs were endogenously expressed in all HOSCC cell lines. We then determined the effect of TNF- $\alpha$ and IL-23 on the expression levels of IL-23 and RelA mRNA by treating HSC- 3 cells with $10 \mathrm{ng} / \mathrm{ml}$ TNF- $\alpha$ or IL- 23 over a time course (Fig. 2A and B). TNF- $\alpha$ and IL-23 induced a rapid increase in the levels of both IL-23 and RelA mRNA. TNF- $\alpha$ stimulation led to a more rapid peak of IL-23 and RelA expression at $30 \mathrm{~min}$, after which mRNA levels reached a plateau, whereas IL-23 stimulation led to a peak of expression of both genes at $60 \mathrm{~min}$ and subsequent plateau. Moreover, to confirm whether IL-23 affected specifically in HSC-3 cells, inhibition assay for IL-23 was performed by stimulating cells with IL-23 in the presence of PAb IL-23p19, a neutralizing polyclonal antibody against IL-23, and analyzing the relative quantities of IL-23 and RelA mRNA by quantitative RT-PCR (Fig. 2C). Treatment of HSC-3 cells with IL-23 together with PAb IL23 p19 suppressed expression of IL-23 and RelA mRNA, whereas control treatment with goat IgG had no effect on expression of these genes. Taken together, these results suggest that TNF- $\alpha$ and IL-23 induce the expression of IL-23 and RelA and that IL-23 may play a critical role in the proliferative activity of HOSCC cells.

Detection of heterodimeric IL-23 in the culture supernatant of HSC-3 cells. We used a specific ELISA to confirm whether 
A

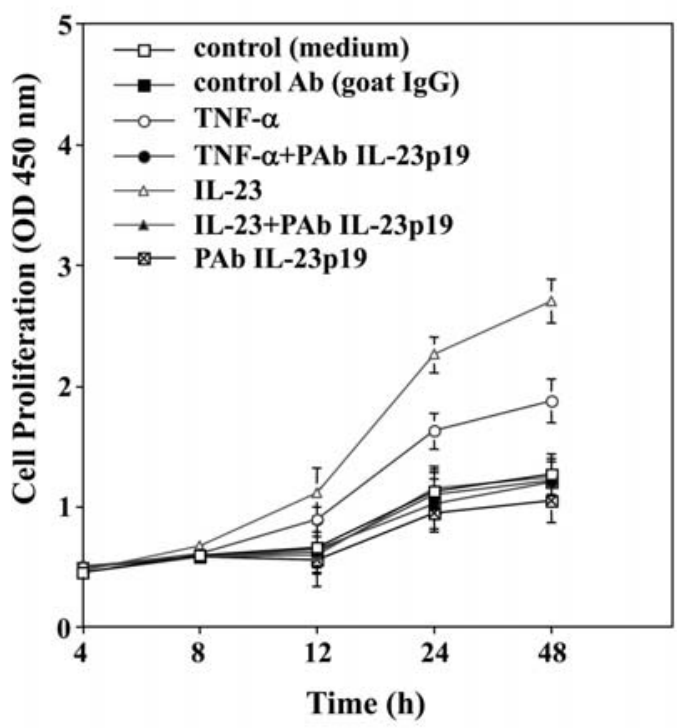

B

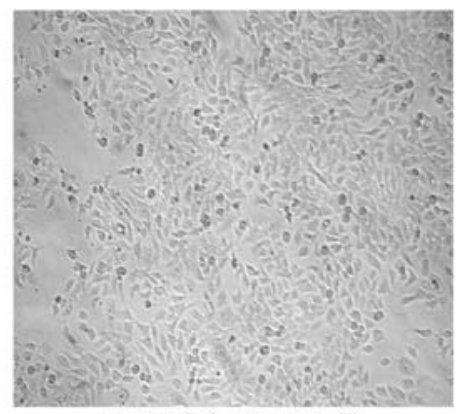

control (untreated)

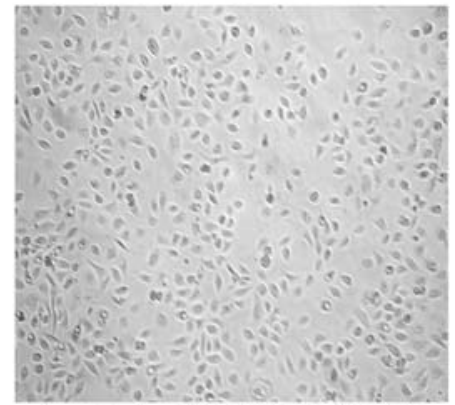

treated with PAb IL-23p19

Figure 4. Cell proliferation assay and confocal laser microscopy. HSC-3 cells were incubated with TNF- $\alpha$ (10 ng/ml) or IL-23 (10 ng/ml) in the presence or absence of PAb IL-23p19 $(0.8 \mu \mathrm{g} / \mathrm{ml})$ for various time periods $(4,8,12,24$ and $48 \mathrm{~h})$. HSC-3 cell numbers increased in a time-dependent manner after treatment with $10 \mathrm{ng} / \mathrm{ml}$ of IL-23, and after 2 days culture, it reached by approximately 5 -fold in comparison with the data of $4 \mathrm{~h}$ treatment (A). At $48 \mathrm{~h}$, the number of cells treated with IL-23 had increased by approximately 2-fold compared with the untreated control. The increase in cell number was lower after treatment with TNF- $\alpha$ than with IL-23. The number of HSC-3 cells treated with IL-23 or TNF- $\alpha$ in the presence of PAb IL-23p19 was lower than that caused by the treatment of cells with TNF- $\alpha$ or IL-23 with the cell number ultimately being reduced to the control level. Cell numbers were slightly lower than that of controls $48 \mathrm{~h}$ after treatment with PAb IL-23p19 alone. We used goat anti-human IgG (H\&L) antibody as a control for the effect of PAb IL-23p19. No significant morphological changes were observed by confocal laser microscopy in the cell structure of HSC-3 treated with PAb IL-23p19 (B).

heterodimeric IL-23 is secreted into the culture supernatant of HOSCC cell lines. The level of heterodimeric IL-23 was below the detectable limit $(1.5 \mathrm{pg} / \mathrm{ml})$ in the supernatant of untreated HSC- 3 cells, but the level increased markedly after treatment by TNF- $\alpha$ in a time-dependent manner (Fig. 3). The maximum amount of TNF- $\alpha$-induced heterodimeric IL-23 was observed after $24 \mathrm{~h}$ and this was an increase of over 8 -fold compared with cells not treated with TNF- $\alpha$. This finding suggests that HSC-3 cells secrete a low level of IL-23 that is markedly increased by TNF- $\alpha$.

IL-23 promotes proliferation of HSC-3 cells. We investigated whether IL-23 promotes the proliferation of HSC-3 cells by carrying out a cell proliferation assay (Fig. 4A). The cell proliferation assay showed that HSC-3 cell numbers increased in a time-dependent manner after treatment with $10 \mathrm{ng} / \mathrm{ml}$ of IL-23, and after 2 days culture, it reached by approximately 5 -fold in comparison with the data of $4 \mathrm{~h}$ treatment. At $48 \mathrm{~h}$ after treatment with $10 \mathrm{ng} / \mathrm{ml} \mathrm{IL-23,} \mathrm{the} \mathrm{cell} \mathrm{number} \mathrm{had}$ increased by approximately 2 -fold compared with the untreated control. The increase in cell number was lower after treatment with $10 \mathrm{ng} / \mathrm{ml} \mathrm{TNF-} \alpha$ than with $10 \mathrm{ng} / \mathrm{ml} \mathrm{IL-23.} \mathrm{We} \mathrm{then}$ treated HSC- 3 cells with IL-23 or TNF- $\alpha$ in the presence of PAb IL-23p19, a neutralizing antibody specific for IL-23. PAb IL-23p19 abolished the induction of cell proliferation by TNF- $\alpha$ or IL-23 with the HSC-3 cell number ultimately reducing to the control level, cell numbers were slightly higher than that of controls $48 \mathrm{~h}$ after treatment with PAb IL-23p19 alone though. This result indicates that promotion of cell proliferation is a specific effect of IL-23, and further that IL-23 has a stronger cell proliferative effect than TNF- $\alpha$ in oral SCC. We then investigated whether the inhibition of cell proliferation by PAb IL-23p19 is the result of apoptosis or a specific effect against cell proliferation via the neutralization of IL-23. Since the apoptosis rapidly induces dramatic effects on cell structure, the effect of PAb IL-23p19 in HSC-3 cells was examined by confocal laser microscopy (Fig. 4B). We found no significant morphological changes in the cell structure of HSC-3. This result suggests that the inhibition of cell proliferation by PAb IL-23p19 is due to a specific effect for cell proliferation via the neutralization of IL-23, but not the result of apoptosis.

IL-23 induces RelA nuclear translocation in HSC-3 cells. To examine how RelA expression is regulated in HSC-3 cells upon stimulation with TNF- $\alpha$ or IL-23, immunoblot analysis was carried out followed by densitometric analysis. RelA protein was localized to the cytoplasm of HSC-3 cells and was transported to the nucleus upon stimulation with TNF- $\alpha$ or IL-23, an effect that reached a peak after 30 min (Fig. 5). It was also found that IL-23 induced the nuclear transactivation of RelA slightly stronger than that of TNF- $\alpha$. Analysis of the time course of RelA protein expression up to $24 \mathrm{~h}$ revealed a decrease in the rate of nuclear translocation of RelA (data not shown).

Regulation of RelA expression in HSC-3 cells after treatment with IL-23 in the presence of PAb IL-23p19 was also analyzed. RelA was primarily localized in the cytoplasm 


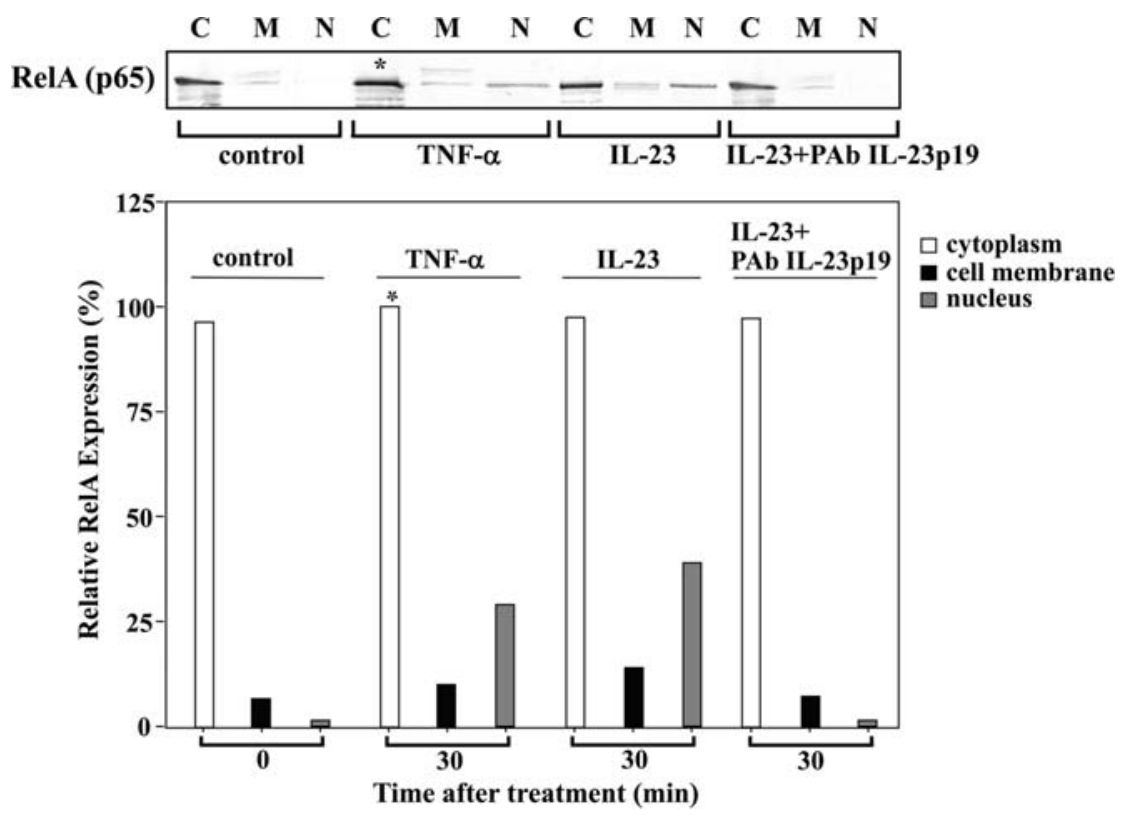

Figure 5. Nuclear transactivation of RelA. HSC-3 cells were treated with or without TNF- $\alpha$ (10 ng/ml), IL-23 (10 ng/ml), or IL-23 (10 ng/ml) + PAb IL-23p19 $(0.8 \mu \mathrm{g} / \mathrm{ml})$ for $30 \mathrm{~min}$. RelA protein was localized to the cytoplasm of HSC-3 cells and was transported to the nucleus upon stimulation with TNF- $\alpha$ or IL-23, an effect that reached a peak after $30 \mathrm{~min}$. TNF- $\alpha$ and IL-23 induced RelA transportation to the nucleus and that PAb IL-23p19 complete inhibited the nuclear translocation of RelA protein. Immunoblot analysis was also evaluated by densitometric analysis. Filters were scanned and computer-generated images were analyzed with the National Institutes of Health IMAGE program to obtain densitometric values. For each series of samples (cytoplasm, cell membrane and nucleus), the relative density of each image was calculated and expressed as a percentage of the value (arbitrarily set at 100) indicated by an asterisk. C, cytoplasm; M, cell membrane; N, nucleus.

with small quantities also detected in the cell membrane; however, RelA transport to the nucleus was almost nothing in HSC-3 cells treated with $10 \mathrm{ng} / \mathrm{ml} \mathrm{IL-23} \mathrm{and} 0.8 \mu \mathrm{g} / \mathrm{ml}$ PAb IL-23p19 for $30 \mathrm{~min}$ (Fig. 5). Hence, we found that IL-23 promotes nuclear translocation of RelA in oral SCC. As shown in Fig. 2C, a decrease in the level of IL-23 mRNA in HSC-3 cells treated with PAb IL-23p19 was observed by real-time quantitative RT-PCR, and that RelA mRNA was also markedly down-regulated almost immediately after treatment. Taken together, these results show that IL-23 induces RelA transportation to the nucleus and that PAb IL23p19 completely inhibits the nuclear translocation of RelA protein, even though the relative quantity of RelA mRNA is observed. Thus, the down-regulation of IL-23 by PAb IL23p19 suppresses RelA activity in HSC-3 cells. This result is suggestive of the existence of an autocrine mechanism, in which tumor growth is promoted by the IL-23 produced by autologous cancer cells. Furthermore, this effect may play a critical role in proliferative activity of HSC-3 cells.

We next investigated the effect of TNF- $\alpha$ or IL-23 on RelA-dependent transcriptional activity in HSC-3 cells by using a luciferase reporter assay. Both TNF- $\alpha$ and IL-23 caused strong induction of luciferase activity (Fig. 6A and B). In HSC-3 cells stimulated with TNF- $\alpha$, RelA-dependent transcription was gradually increased in a time-dependent manner. Maximum RelA-dependent transcription was observed after $24 \mathrm{~h}$, with a 6.5-fold increase in luciferase activity, compared with cells not exposed to TNF- $\alpha$. Similarly, in HSC-3 cells stimulated with IL-23, maximum RelA-dependent transcription was also observed after $24 \mathrm{~h}$, with a 9-fold increase in luciferase activity compared with cells not exposed to IL-23. Thus, IL-23 induced a stronger RelA-dependent transcriptional activity than TNF- $\alpha$. To examine whether constitutive RelA activity was observed in HSC-3 cells, a luciferase reporter assay was performed in the absence of TNF- $\alpha$ or IL-23 for the indicated time periods. We found that there was no constitutive RelA activity in HSC-3 cells (Fig. 6C). Furthermore, the blocking of constitutive IL-23 expression by PAb IL-23p19 has no effect on constitutive RelA activity. These findings suggest that constitutive IL-23 expression is not associated with RelA activation in HSC-3 cells. In addition, the increase in luciferase activity was completely dependent on the presence of $\kappa \mathrm{B}$ sites, since the control plasmid lacking the $\kappa \mathrm{B}$ elements did not respond to TNF- $\alpha$ or IL-23 (Fig. 6D). We then attempted a luciferase reporter assay to test whether PAb IL-23p19, used for neutralization of IL-23, can suppress induction of luciferase activity by TNF- $\alpha$ or IL-23. PAb IL-23p19 down-regulated luciferase activity in HSC-3 cells with half-maximal inhibition of luciferase activity detected $4 \mathrm{~h}$ after PAb IL-23p19 treatment (Fig. 6A and B). Taken together, these data indicate that production of IL-23 is induced by TNF- $\alpha$ or IL-23, which in turn increases RelA-dependent transcriptional activity in HSC -3 cells.

IL-23 up-regulates RelA activation in HSC-3 cells. To determine whether endogenous IL-23 functions as an up-regulator of RelA activation by TNF- $\alpha$ in HSC- 3 cells, we used an siRNA approach to reduce the expression of IL-23 and determined the effects on the basal and TNF- $\alpha$-induced activity of RelA. As expected, the level of the IL-23 protein was markedly reduced by IL-23 siRNA (Fig. 7A). We then assessed the effect of IL-23 siRNA on RelA-dependent transcriptional activity by TNF- $\alpha$ over 4 h. As shown in Fig. 7B, IL-23 knockdown 
A

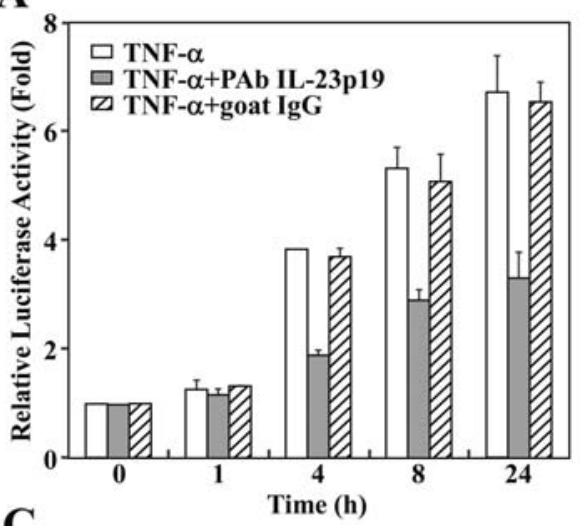

C

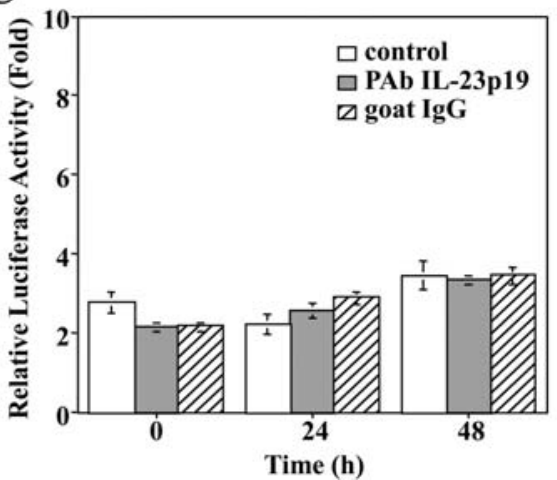

B

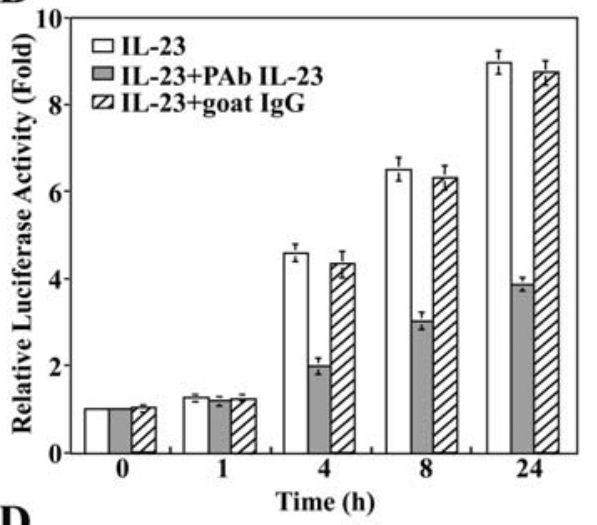

D

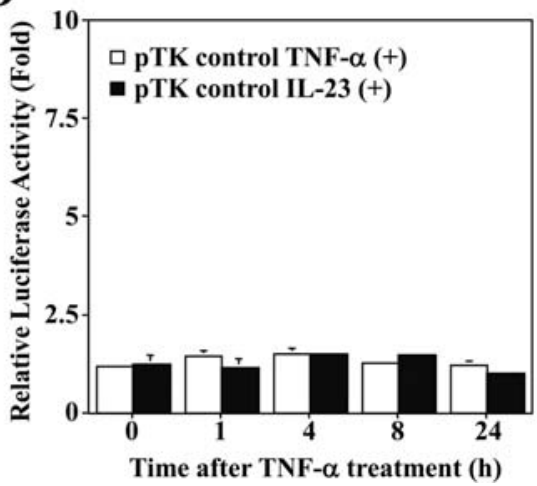

Figure 6. Luciferase reporter assay. The cells were transfected with the plasmids and $24 \mathrm{~h}$ later the cells were treated with TNF- $\alpha$ (10 ng/ml), or IL-23 (10 ng/ml), TNF- $\alpha(10 \mathrm{ng} / \mathrm{ml})$ together with PAb IL-23p19 $(0.8 \mu \mathrm{g} / \mathrm{ml})$, or IL-23 (10 ng/ml) together with PAb IL-23p19 (0.8 $\mu \mathrm{g} / \mathrm{ml})$, or TNF- $\alpha(10 \mathrm{ng} / \mathrm{ml})$ together with goat anti-human $\operatorname{IgG}(0.8 \mu \mathrm{g} / \mathrm{ml})$, or IL-23 $(10 \mathrm{ng} / \mathrm{ml})$ together with goat anti-human IgG $(0.8 \mu \mathrm{g} / \mathrm{ml})$ for various time periods $(0,1,4,8$ and $24 \mathrm{~h})$. We used goat anti-human IgG (H\&L) antibody as a control for the effect of PAb IL-23p19. A luciferase reporter assay indicated the effect of TNF- $\alpha$ and PAb IL-23p19 on RelA-dependent transcriptional activity in HSC-3 cells (A). A luciferase reporter assay indicated the effect of IL-23 and PAb IL-23p19 on RelAdependent transcriptional activity in HSC-3 cells (B). A luciferase reporter assay was performed with PAb IL-23p19 or goat anti-human IgG in the absence of TNF- $\alpha$ and IL-23 for the indicated times (0, 24 and 48 h) (C). Constitutive RelA activity was not observed in HSC-3 cells. Furthermore, the blocking of constitutive IL-23 expression by PAb IL-23p19 had no effect on constitutive RelA activity. The increase in luciferase activity was completely dependent on the presence of $\kappa \mathrm{B}$ sites, since the control plasmid lacking the $\kappa \mathrm{B}$ elements did not respond to TNF- $\alpha$ or IL-23 (D). Relative luciferase activities are shown as fold induction compared with the activity of untreated sample (A) or pTK control IL-23 (+) sample at 24 h (D). Each column and bar represents the mean \pm SEM of three independent experiments.

A

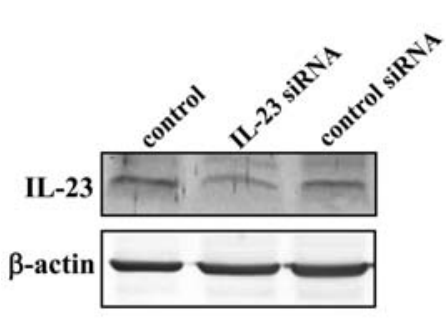

B

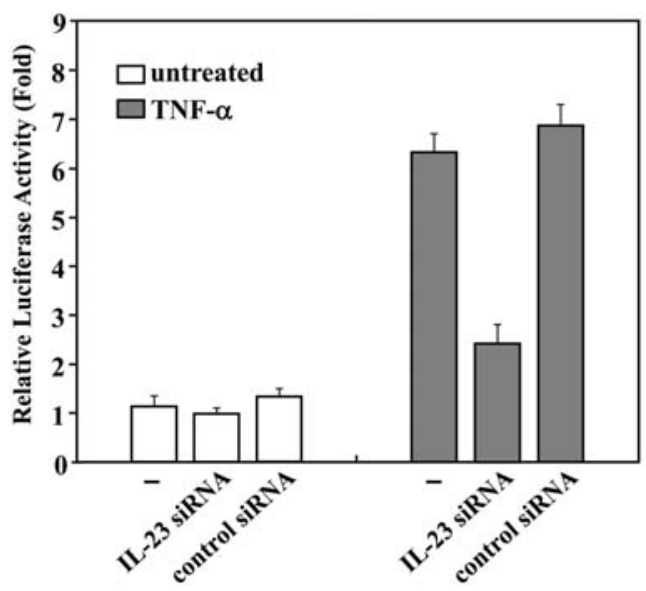

Figure 7. IL-23 siRNA-mediated interference. HSC-3 cells $\left(1 \times 10^{5}\right.$ cells/ml) were transfected with a RelA-dependent luciferase reporter plasmid and either an IL-23 siRNA duplex or a control siRNA for $48 \mathrm{~h}$. Cells were treated with TNF- $\alpha$ for $4 \mathrm{~h}$, and subjected to immunoblot analysis and luciferase reporter assay analysis. The endogenous level of the IL-23 protein was markedly reduced by IL-23 siRNA (A). A luciferase reporter assay indicated that IL-23 knockdown by IL-23 siRNA greatly reduced RelA activation by TNF- $\alpha$ in HSC-3 cells compared with the scrambled siRNA control (B). However, IL-23 siRNA had no effect on constitutive RelA activity in HSC-3 cells. The relative luciferase activities are shown as fold induction compared with the activity of untreated samples. Each column and bar represents the mean \pm SEM of three independent experiments. 
Table I. Correlation between the expression of IL-23, NF-кB and clinicopathological variables in 40 cases of oral squamous cell carcinomas.

\begin{tabular}{|c|c|c|c|c|c|c|c|c|}
\hline \multirow[t]{2}{*}{ No. } & \multirow[t]{2}{*}{ Age } & \multirow[t]{2}{*}{ Gender } & \multirow[t]{2}{*}{ Location } & \multirow[t]{2}{*}{ Differentiation } & \multirow[t]{2}{*}{ pTNM } & \multirow[t]{2}{*}{ Stage } & \multicolumn{2}{|c|}{ Immunohistochemistry } \\
\hline & & & & & & & IL-23 & $\mathrm{NF}-\kappa \mathrm{B}$ \\
\hline 1 & 87 & M & Oral floor & Well & $\mathrm{T} 2 \mathrm{~N} 2 \mathrm{bM} 0$ & IVA & + & + \\
\hline 2 & 48 & $\mathrm{~F}$ & Gingiva & Well & T4N0M0 & IVA & - & + \\
\hline 3 & 56 & $\mathrm{~F}$ & Buccal mucosa & Well & T2N0M0 & II & - & + \\
\hline 4 & 75 & M & Tongue & Well & T4N2cM0 & IVA & + & + \\
\hline 5 & 55 & M & Oral floor & Well & T2N0M0 & II & + & + \\
\hline 6 & 54 & M & Tongue & Well & T4N2bM0 & IVA & - & + \\
\hline 7 & 54 & M & Oral floor & Well & T2N2aM0 & IVA & - & + \\
\hline 8 & 70 & M & Tongue & Well & T2N0M0 & II & - & + \\
\hline 9 & 67 & M & Maxillary gingiva & Well & T4N3M0 & IVB & - & + \\
\hline 10 & 92 & M & Soft palate & Well & T2N0M0 & II & - & - \\
\hline 11 & 66 & M & Tongue & Well & T2N0M0 & II & - & + \\
\hline 12 & 87 & M & Tongue & Well & T2N0M0 & II & - & - \\
\hline 13 & 48 & $\mathrm{~F}$ & Tongue & Well & T1N0M0 & I & - & - \\
\hline 14 & 85 & M & Tongue & Well & T2N1M0 & III & + & - \\
\hline 15 & 56 & $\mathrm{~F}$ & Tongue & Well & $\mathrm{T} 1 \mathrm{~N} 2 \mathrm{bM} 0$ & IVA & - & + \\
\hline 16 & 67 & M & Mandibular gingiva & Well & $\mathrm{T} 1 \mathrm{~N} 2 \mathrm{bM} 0$ & IVA & + & + \\
\hline 17 & 55 & M & Tongue & Well & T1N0M0 & I & + & + \\
\hline 18 & 85 & M & Buccal mucosa & Well & T1N0M0 & I & + & - \\
\hline 19 & 50 & M & Mandibular gingiva & Well & T3N1M0 & III & + & + \\
\hline 20 & 67 & M & Mandibular gingiva & Well & T4N0M0 & IVA & + & + \\
\hline 21 & 79 & M & Buccal mucosa & Well & T2N0M0 & II & + & + \\
\hline 22 & 54 & M & Buccal mucosa & Well & T1N0M0 & I & - & + \\
\hline 23 & 54 & M & Mandibular gingiva & Well & T4N1M0 & IVA & - & - \\
\hline 24 & 62 & M & Mandibular gingiva & Well & T1N0M0 & I & + & + \\
\hline 25 & 60 & M & Maxillary gingiva & Well & T1N0M0 & I & + & - \\
\hline 26 & 79 & M & Mandibular gingiva & Moderately & T4N2cM0 & IVA & - & + \\
\hline 27 & 85 & $\mathrm{~F}$ & Tongue & Moderately & T2N1M0 & III & - & + \\
\hline 28 & 54 & M & Tongue & Moderately & T1N0M0 & I & - & + \\
\hline 29 & 54 & M & Tongue & Moderately & T4N2bM0 & IVA & - & + \\
\hline 30 & 75 & M & Mandibular gingiva & Moderately & T1N0M0 & I & - & - \\
\hline 31 & 66 & $\mathrm{~F}$ & Mandibular gingiva & Moderately & T1N0M0 & I & - & - \\
\hline 32 & 65 & M & Mandibular gingiva & Moderately & T2N0M0 & II & - & - \\
\hline 33 & 88 & M & Mandibular gingiva & Moderately & T2N0M0 & II & - & + \\
\hline 34 & 79 & M & Mandibular gingiva & Moderately & T2N0M0 & II & - & + \\
\hline 35 & 54 & M & Buccal mucosa & Moderately & T2N0M0 & II & + & + \\
\hline 36 & 64 & M & Buccal mucosa & Poorly & T2N0M0 & II & - & + \\
\hline 37 & 62 & M & Tongue & Poorly & T2N1M0 & III & - & + \\
\hline 38 & 60 & M & Tongue & Poorly & T2N1M0 & III & - & + \\
\hline 39 & 60 & M & Tongue & Poorly & T1N0M0 & I & - & + \\
\hline 40 & 68 & M & Maxillary gingiva & Poorly & T3N0M0 & III & + & + \\
\hline
\end{tabular}

by IL-23 siRNA greatly reduced RelA activation by TNF- $\alpha$ in HSC-3 cells compared with the scrambled siRNA control. However, IL-23 siRNA had no effect on constitutive RelA activity in HSC-3 cells. These data indicate that endogenous IL-23 functions as an up-regulator of RelA activation induced by TNF- $\alpha$ in HSC-3 cells, further suggest that IL-23 produced by autologous cancer cells promotes tumor growth.
Immunohistochemical detection of IL-23 and RelA and clinicopathological variables in SCC tissues. The correlations between IL-23, RelA expression, and clinicopathological variables in SCC tissues are summarized in Table I. Immunohistochemical detection of IL-23 and RelA was carried out in 40 cases of SCC at various stages. A weak positive reaction to PAb IL-23p19 was observed in the cytoplasm of infiltrated 

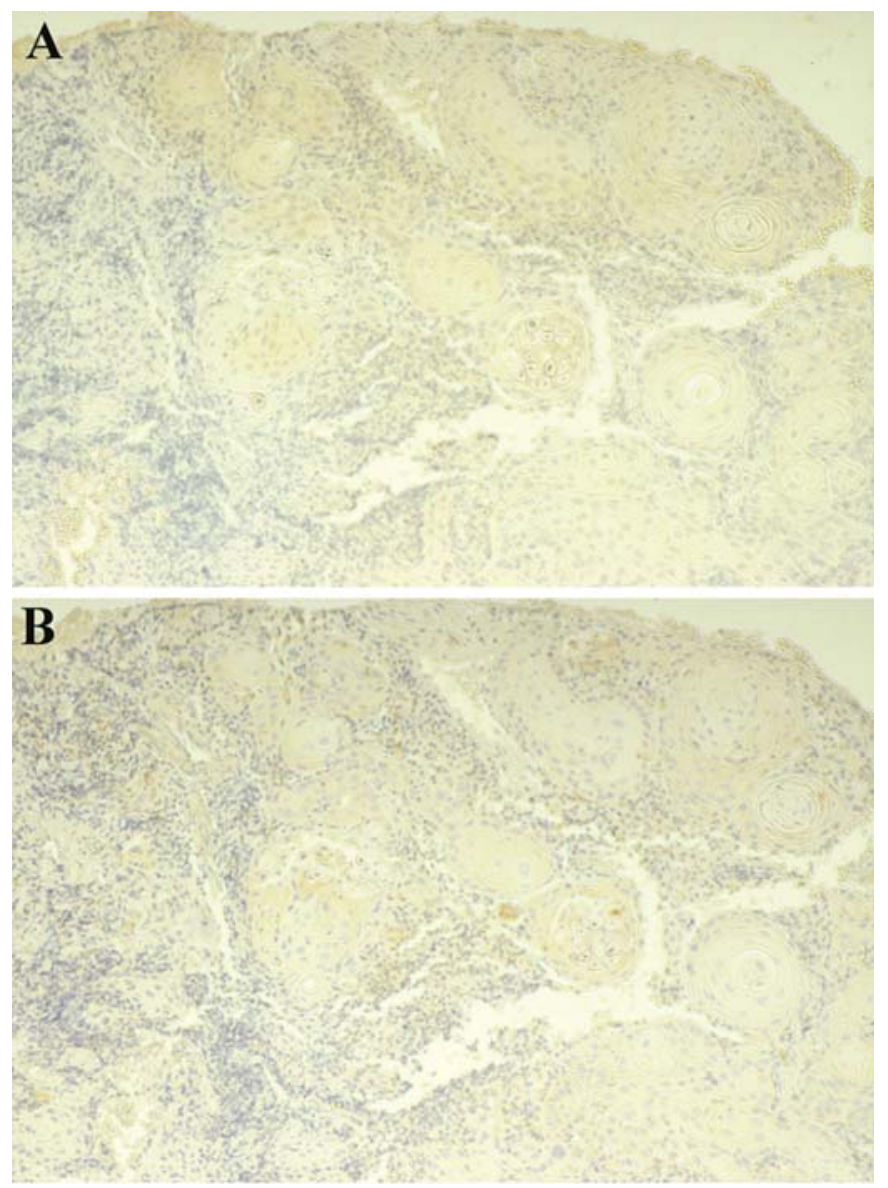

Figure 8. Immunohistochemistry. Immunohistochemical detection of IL-23 and RelA was carried out for 40 cases of SCC at various stages. A weak positive reaction was observed for PAb IL-23p19 in the cytoplasm of cancer cells and infiltrated inflammatory cells (x66) (A). A strong positive reaction for MAb RelA was observed in the cytoplasm of cancer cells, especially consistent with the observation of IL-23-positive cells in SCC tissues (x66) (B).

inflammatory cells and cancer cells in 14 of 40 cases (35\%) of SCC (Fig. 8A). Whereas, strong RelA immunoreactivity was observed in 30 of 40 cases of SCC $(75 \%)$, especially consistent with the observation of IL-23-positive cells in SCC tissues (Fig. 8B).

\section{Discussion}

The epidemiologic relationship between cancer and inflammation has been well established. Many cancers arise at the site of chronic inflammation and inflammatory mediators are often produced in tumors $(2,26)$. The frequent use of antiinflammatory drugs reduces the incidence of a variety of human tumors (27). Although blockading some of these mediators has been shown to be efficacious in experimental settings, it is still unclear whether the inflammatory reaction at the tumor site promotes tumor growth or simply implies the failed attempt of the immune system to eliminate the rising malignancy. However, transgenic mice with chronic inflammatory bowel disease caused by the absence of IL-10 develop colon cancer (28), and the adoptive transfer of inflammationsuppressing regulatory $\mathrm{T}$ cells can inhibit colon polyposis in transgenic mice carrying a mutated adenomatosis polyposis coli (APC) gene (29). In recent years, accumulating evidence has shown that although human tumors are less immunogenic than foreign pathogens, a surprisingly wide range of tumor specific epitopes are recognized by the adaptive immune system (30). Tumor antigen-specific T cells (31), which are cytotoxic to autologous tumor cells in vitro, are found in the circulation and within tumors, and can be expanded therapeutically. Despite the identification of tumor-associated antigens and their application for immunization of patients with cancer, the majority of clinical trials show disappointing results that contrast with the effectiveness of immunotherapy in experimental tumors (32). The basis for this poor clinical outcome may be the ability of cancer cells to escape from destruction by adoptive and innate immunity effector mechanisms. We also observed in our previous study that tumor cells possess the potential to escape immune surveillance by killing host $\mathrm{T}$ lymphocytes through cytokines such as RCAS1 (33).

Cytokines comprise a large family of secreted proteins that bind to and signal through defined cell surface receptors on a wide variety of target cells and play a pivotal role in the establishment and maintenance of homeostasis. Many cytokines share structural features and functions during development, immune response, or inflammation. In a previous study, IL-23 was identified as a cancer-associated cytokine (3). The expression of IL-23, but not that of its close relative IL-12, was significantly increased in the vast majority of human tumors from various organ types when compared with normal adjacent tissue from the same individual (3). The role of IL-23 in tumorigenesis is clearly demonstrated in mice lacking IL-23p19; these mice are almost completely resistant to endogenous tumor formation when challenged in a chemical carcinogenesis protocol (3). By comparison, a sizeable number of reports have described tumor-inhibitory effects of IL-23 in fast growing, immune-sensitive mouse tumor models, genetically engineered to overexpress an IL-23-like product with linked p40 and p19 subunits. Following implantation in immune-naive hosts, IL-23-overexpressing tumors show reduced growth and metastasis consistent with the stimulation of a $\mathrm{CD}^{+}$memory $\mathrm{T}$ cell response (34-38). As described, the precise role of IL-23 and its function at the cancer invasive front is controversial.

In this study, the results of real-time quantitative RT-PCR indicated that IL-23 induced NF- $\mathrm{BB}$ activation, and the IL-23 knockdown analysis suggested that IL-23 regulates $\mathrm{NF}-\mathrm{\kappa B}$ activation induced by TNF- $\alpha$ in HSC-3 cells. It has already been reported that TNF- $\alpha$ induces NF- $\kappa \mathrm{B}$ activation via a common pathway based on the phosphorylation-induced degradation of IкBs (15). In the present study, TNF- $\alpha$ was also used to activate NF- $\mathrm{BB}$ in HSC-3 cells to mimic the local inflammatory response in the metastasized region, and some tumor cells were reported to produce TNF- $\alpha$ (15). We further found that blocking the function of IL-23 inhibits the proliferative activity of tumor cells without inducing apoptosis. As follows, two separate lines of evidence allowed us to conclude that IL-23 is a potent and specific promoter of $\mathrm{NF}-\kappa \mathrm{B}$ activation in HSC-3 cells: i) IL-23 promoted nuclear transactivation of $\mathrm{NF}-\kappa \mathrm{B}$, and ii) IL-23 increased NF-кBdependent transcriptional activity. Indeed, NF- $\mathrm{B}$ controls 
genes that code for anti-apoptotic proteins, some acting at the mitochondrial level (17) or directly blocking caspase activation (39). Up-regulation of NF- $\mathrm{B}$ could therefore result in an increase in crucial anti-apoptotic influences both at the mitochondrial and the membrane death receptor levels. Additionally, we found that although both IL-23 and TNF- $\alpha$ have effects such as increased cell proliferation, promoted nuclear transactivation of $\mathrm{NF}-\kappa \mathrm{B}$ and increased $\mathrm{NF}-\kappa \mathrm{B}-$ dependent transcriptional activity, IL-23 is stronger in each effect than TNF- $\alpha$. Furthermore, our in vivo studies showed strong RelA-specific immunoreactivity in $75 \%$ of SCC cases, especially consistent with the observation of IL-23-positive cells in SCC tissues. These data also suggested that IL-23 might promote $\mathrm{NF}-\kappa \mathrm{B}$ activity, alternatively IL-23 function might be activated by $\mathrm{NF}-\kappa \mathrm{B}$ in SCC tissues. Finally, we noted that IL-23 was secreted not only by DCs and macrophages, as shown in previous studies (4), but also by autologous cancer cells. Consequently, we consider the existence of an autocrine mechanism, in which tumor growth is promoted by IL-23 produced by autologous cancer cells. From these combined data, we believe that IL-23 plays a significant role in the growth and proliferation of oral cancer. Thus, IL-23 could be used as a predictor of poor prognosis in patients with oral cancer, and its antibody might be able to use as an inhibitor of oral cancer progression. Identification of the signaling pathways underlying these events might provide the key to elucidating the mechanism of development of oral cancer. Further investigations into the role of IL-23 will be required to fully understand IL-23-mediated tumor proliferation and to establish an IL-23-based oral cancer therapeutic strategy.

\section{Acknowledgements}

This study was supported by a Grant-in-Aid for scientific research from the Ministry of Education, Science and Culture of Japan.

\section{References}

1. Balkwill $\mathrm{F}$ and Mantovani A: Inflammation and cancer: back to Virchow? Lancet 357: 539-545, 2001.

2. Coussens LM and Werb Z: Inflammation and cancer. Nature 420: 860-867, 2002.

3. Langowski JL, Zhang X, Wu L, Mattson JD, Chen T, Smith K, Basham B, McClanahan T, Kastelein RA and Oft M: IL-23 promotes tumour incidence and growth. Nature 27: 461-465, 2006.

4. Oppmann B, Lesley R, Blom B, et al: Novel p19 protein engages IL-12p40 to form a cytokine, IL-23, with biological activities similar as well as distinct from IL-12. Immunity 13: 715-725, 2000 .

5. Sospedra M and Martin R: Immunology of multiple sclerosis. Annu Rev Immunol 23: 683-747, 2005.

6. Parham C, Chirica M, Timans J, et al: A receptor for the heterodimeric cytokine IL-23 is composed of IL-12Rbeta1 and a novel cytokine receptor subunit, IL-23R. J Immunol 168: 5699-5708, 2002.

7. Lankford CSR and Frucht DM: A unique role for IL-23 in promoting cellular immunity. J Leukocyte Biol 73: 49-56, 2003.

8. Brunda MJ, Luistro L, Warrier RR, et al: Antitumor and antimetastatic activity of interleukin 12 against murine tumors. J Exp Med 178: 1223-1230, 1993.

9. Nastala CL, Edington HD, McKinney TG, et al: Recombinant IL-12 administration induces tumor regression in association with IFN-production. J Immunol 153: 1697-1706, 1994.
10. Cua DJ, Sherlock J, Chen Y, et al: Interleukin-23 rather than interleukin-12 is the critical cytokine for autoimmune inflammation of the brain. Nature 421: 744-748, 2003.

11. Murphy CA, Langrish CL, Chen Y, et al: Divergent pro- and anti-inflammatory roles for IL-23 and IL-12 in joint auto-immune inflammation. J Exp Med 198: 1951-1957, 2003.

12. Becher B, Durell BG and Noelle RJ: IL-23 produced by CNSresident cells controls $\mathrm{T}$ cell encephalitogenicity during the effector phase of experimental autoimmune encephalomyelitis. J Clin Invest 112: 1186-1191, 2003.

13. Piskin G, Sylva-Steenland RMR, Bos JD and Teunissen MBM: In vitro and in situ expression of IL-23 by keratinocytes in healthy skin and psoriasis lesions: enhanced expression in psoriatic skin. J Immunol 176: 1908-1915, 2006.

14. Fukuda M, Ehara M, Suzuki S and Sakashita H: Expression of interleukin-23 and its receptors in human squamous cell carcinoma of the oral cavity. Mol Med Rep 3: 89-93, 2010.

15. Karin M: How NF-кB is activated: the role of the IкB kinase (IKK) complex. Oncogene 18: 6867-6874, 1999.

16. Li Q and Verma IM: NF-kappaB regulation in the immune system. Nat Rev Immunol 2: 725-734, 2002.

17. Karin M, Cao Y, Greten FR and Li ZW: NF-кB in cancer: from innocent bystander to major culprit. Nat Rev Cancer 2: 301-310, 2002.

18. Orlowski RZ and Baldwin AS Jr: NF-kappaB as a therapeutic target in cancer. Trends Mol Med 8: 385-389, 2002.

19. Baeuerle PA and Baltimore D: I kappa B: a specific inhibitor of the NF-kappa B transcription factor. Science 242: 540-546, 1988.

20. Rodriguez MS, Thompson J, Hay RT and Dargemont C: Nuclear retention of IкB $\alpha$ protects it from signal-induced degradation and inhibits nuclear factor $\mathrm{\kappa B}$ transcriptional activation. J Biol Chem 274: 9108-9115, 1999.

21. Smahi A, Courtois G, Rabia SH, et al: The NF-kappaB signalling pathway in human diseases: from incontinentia pigmenti to ectodermal dysplasias and immune-deficiency syndromes. Hum Mol Genet 11: 2371-2375, 2002.

22. Fukuda M, Horiuchi Y, Oku Y, et al: Induction of apoptosis in human salivary gland tumor cells by anti-NCAM antibody. Oncol Rep 14: 1143-1149, 2005.

23. Ohmori Y and Hamilton TA: Interleukin-4/STAT6 represses STAT1 and NF-kappa B-dependent transcription through distinct mechanisms. J Biol Chem 275: 38095-38103, 2000.

24. Pindborg JJ, Reichart PA, Smith CJ and van der Waal I: Histological typing of cancer and precancer of the oral mucosa. World Health Organization International Histological Classification of tumors. 2nd edition, Springer-Verlag, Berlin, pp11-38, 1997.

25. Sobin LH and Wittekind CH (eds). UICC TNM classification of malignant tumors. 5th edition, John Wiley and Sons, Inc., New York, pp20-24, 2002.

26. Balkwill F, Charles KA and Mantovani A: Smoldering and polarized inflammation in the initiation and promotion of malignant disease. Cancer Cell 7: 211-217, 2005.

27. Zha S, Yegnasubramanian V, Nelson WG, Isaacs WB and De Marzo AM: Cyclooxygenases in cancer: progress and perspective. Cancer Lett 215: 1-20, 2004.

28. Berg DJ, Davidson N, Kühn R, et al: Enterocolitis and colon cancer in interleukin-10-deficient mice are associated with aberrant cytokine production and $\mathrm{CD}^{+}{ }^{+} \mathrm{TH} 1$-like responses. J Clin Invest 98: 1010-1020, 1996.

29. Erdman SE, Sohn JJ, Rao VP, Nambiar PR, Ge Z, Fox JG and Schauer DB: $\mathrm{CD}^{+}{ }^{+} \mathrm{CD} 25^{+}$regulatory lymphocytes induce regression of intestinal tumors in ApcMin/+ mice. Cancer Res 65: 3998-4004, 2005.

30. Jäger E, Jäger D and Knuth A: Antigen-specific immunotherapy and cancer vaccines. Int J Cancer 106: 817-820, 2003.

31. Pittet MJ, Valmori D, Dunbar PR, et al: High frequencies of naive Melan-A/MART-1-specific $\mathrm{CD}^{+} \mathrm{T}$ cells in a large proportion of human histocompatibility leukocyte antigen (HLA)-A2 individuals. J Exp Med 190: 705-715, 1999.

32. Rosenberg SA, Sherry RM, Morton KE, et al: Tumor progression can occur despite the induction of very high levels of self/tumor antigen-specific $\mathrm{CD}^{+} \mathrm{T}$ cells in patients with melanoma. J Immunol 175: 6169-6176, 2005.

33. Fukuda M, Tanaka A, Hamao A, Suzuki S, Kusama K and Sakashita H: Expression of RCAS1 and its function in human squamous cell carcinoma of the oral cavity. Oncol Rep 12: 259-267, 2004. 
34. Shimozato O, Ugai S, Chiyo M, et al: The secreted form of the p40 subunit of interleukin (IL)-12 inhibits IL-23 functions and abrogates IL-23-mediated antitumour effects. Immunology 117: $22-28,2006$

35. Shan BE, Hao JS, Li QX and Tagawa M: Antitumor activity and immune enhancement of murine interleukin-23 expressed in murine colon carcinoma cells. Cell Mol Immunol 3: 47-52, 2006.

36. Shan B, Yu L, Shimozato O, Li Q and Tagawa M: Expression of interleukin-21 and -23 in human esophageal tumors produced antitumor effects in nude mice. Anticancer Res 24 $79-82,2004$
37. Lo CH, Lee SC, Wu PY, et al: Antitumor and antimetastatic activity of IL-23. J Immunol 171: 600-607, 2003.

38. Overwijk WW: Breaking tolerance in cancer immunotherapy: time to ACT. Curr Opin Immunol 17: 187-194, 2005.

39. Deveraux Q and Reed J: IAP family proteins: suppressors of apoptosis. Genes Dev 13: 239-252, 1999. 